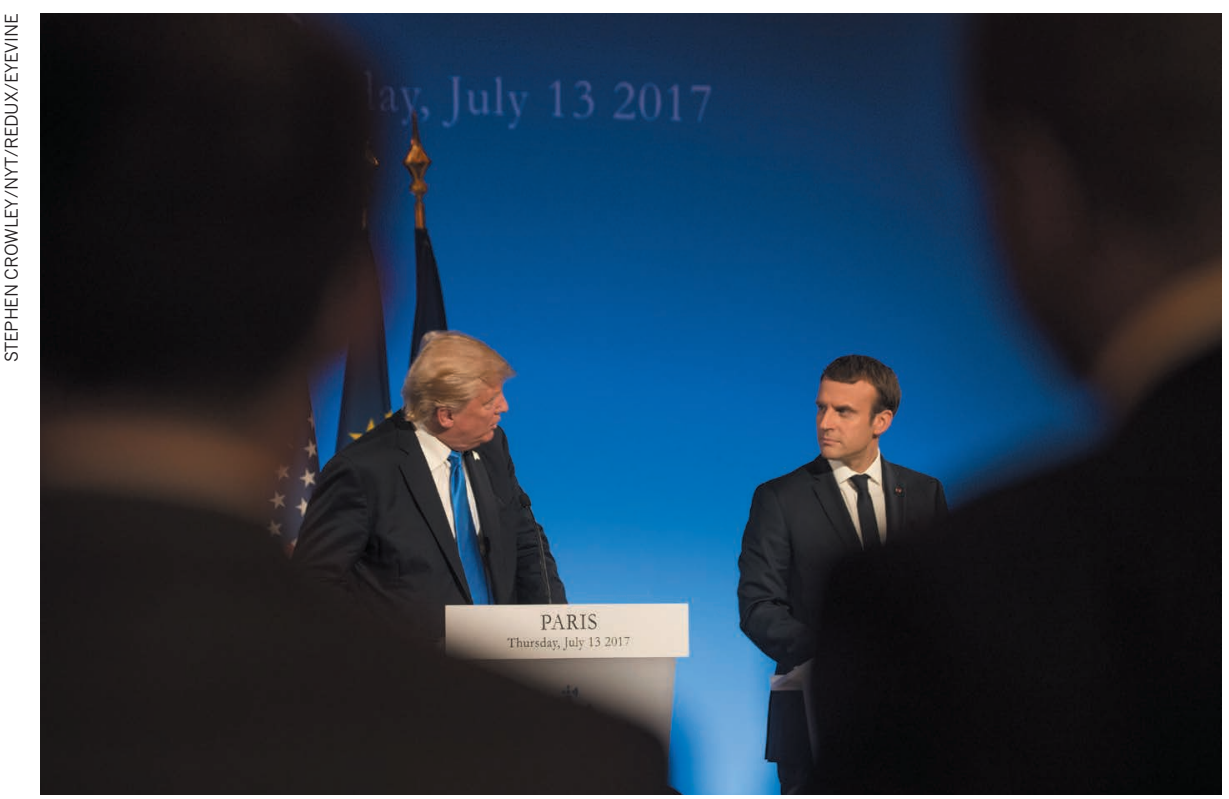

French President Emmanuel Macron (right) with his US counterpart, Donald Trump.

FUNDING

\section{Climate scientists flock to France's call}

\author{
President said 'Make Our Planet Great Again' - and \\ researchers signed up.
}

$\mathrm{H}$ undreds of climate scientists, including many from the United States, have applied to work in France under a $€ 60$-million (US\$69-million) scheme set up by the country's president, Emmanuel Macron, after his US counterpart Donald Trump rejected the Paris accord on global warming. And Germany has announced that it will set up a similar programme to lure researchers.

Macron launched his 'Make Our Planet Great Again' initiative on 8 June, seeking to entice foreign scientists to France with offers of 4-year grants worth up to $€ 1.5$ million. Six weeks on, the programme has been flooded with applicants. Many were seeking short sabbaticals, but the 154 who applied to stay
"There are very few funding opportunities in the United States that promote research on carbon-climate interactions at the global scale, so the fact this programme was looking for visionary thinking was appealing," he says.

The French offer is a "very attractive proposition for many scientists in the US", says Kim Cobb, a palaeoclimatologist at the Georgia Institute of Technology in Atlanta. US climate science is under pressure, she adds: researchers are waiting to hear whether Congress will approve Trump's proposed drastic cuts to the field. Cobb says that, were she not a tenured scientist working in an exceptional research environment, she would be "jumping at the opportunity" to work in France.

\section{GERMAN BACKING}

Officials in Germany announced on 13 July that they will establish a scheme to operate alongside the French programme. The German fund will comprise $€ 15$ million of government money, matched by a sum from the country's participating research organizations. Details of the programme are not yet finalized, but Germany's research ministry has created a website (go.nature.com/2vxxgme) where interested researchers can sign up. Peyroche says the German fund will target younger or more-junior scientists than its French counterpart.

Climate scientists in France support Macron's political stance on the Paris agreement. But a vocal minority of researchers argues that the scheme is largely a public-relations exercise to boost France's image abroad while research funds at home are scarce. The French government last week proposed trimming the 2017 budget for research and higher education by $€ 331$ million, as part of more than $€ 3$ billion of cuts in public spending to pay for new initiatives without increasing the national deficit.

"These numbers should make any foreign scientist wonder about the generous invitation of President Macron to relocate to France," says Patrick Lemaire, a biologist at the University of Montpellier and founder of the researcher-led campaign group Sciences en Marche. But Sacha Wunsch-Vincent, an economist at the World Intellectual Property Organization in Geneva, Switzerland, says that Macron's prominent overtures to foreign scientists and entrepreneurs are helping to promote France as a good place to do research and innovation. "There is a seismic shift in the branding of France," he says. -

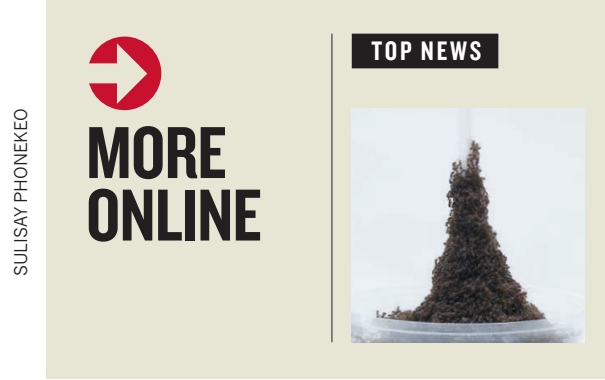

Fire-ant colonies behave like fluid to build tall towers go.nature. com/2uuuyb7

\section{MORE NEWS}

- Lights, camera, CRISPR: Biologists use gene editing to store movies in DNA go.nature.com/2vxirc3

- World's largest hoard of carbon dates goes global go.nature.com/2tbplde - Quantum teleportation might not be what you think go.nature.com/2uyarly

\section{NATURE PODCAST}

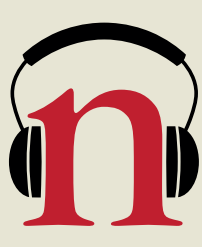

Getting a handle on topology, and working out why the fastest animals are medium-sized nature.com/nature/ podcast 